\title{
Energy-saving potential of heating networks in Russia
}

\author{
Natalya Gagulina, ${ }^{1, *}$ and Andrei Zaedinov ${ }^{2}$ \\ ${ }^{1}$ Institute for Regional Economic Studies Russian Academy of Sciences, 38, Serpuhovskaya str., \\ 190013, Saint Petersburg, Russia \\ ${ }^{2}$ ITMO University, Faculty of Technological Management and Innovations, 49, Kronverksky ave., \\ 197101, Saint Petersburg, Russia
}

\begin{abstract}
The paper is devoted to the study and search for solutions to one of the most important problems within the modern Russian economy - the problem of energy saving. The relevance of this topic is due to the unprofitability of the heat supply industry, the one main reasons of which is the unsatisfactory condition of fixed assets. The paper considers the most important element of heat supply: the transfer of heat energy to consumers through the heat network. It has been presented an overview and analysis of the state of heating networks in 2014-2019 on average in Russia and particularly: in Moscow, St. Petersburg, and the Northwestern Federal District. The value of economic losses incurred by heat supply organizations due to heat losses in their heating networks is obtained. In monetary terms, the energy-saving potential was obtained while reducing heat losses in the pipelines up to $4 \%$. For the whole country, this potential amounted to more than 100 billion rubles a year. As the analysis of the experience of foreign countries with similar climatic conditions, such as Denmark, Norway, and Finland, has shown, Russia can significantly increase the efficiency of heat supply through the use of innovative technologies.
\end{abstract}

\section{Introduction}

The energy intensity of Russian GDP in 2018 exceeded the world level by $46 \%$, the level of the United States-by 44\%, Canada-by 17\% (State Report on the state of Energy Conservation and Energy Efficiency Improvement in the Russian Federation, Moscow, Ministry of Economic Development, 2019). Among the sectors of the economy, the largest contribution to the increase in the energy intensity of GDP in 2015-2018 was made by the manufacturing industry and the housing sector. Thus, the consumption of fuel and energy resources increased by 3.2 million tons. On average, in Russia, 1,530 MJ/m2 is annually spent on the needs of heating residential buildings from centralized systems, while in Germany and Sweden these figures are $936 \mathrm{MJ} / \mathrm{m} 2$ and $486 \mathrm{MJ} / \mathrm{m} 2$, respectively. According to the experts, the energy-saving potential in the Russian housing and communal services is $30-34 \%$ of the total resource consumption. The implementation of energy-saving technologies will not only reduce energy consumption but in the future, it will inevitably

\footnotetext{
*Corresponding author: Nata_C@bk.ru
} 
improve the quality of life, which is determined by the totality of factors of human existence and development [1].

\section{Materials and methods}

According to the Report on the state of the heat and power industry and heat supply in the Russian Federation for 2015-2016 of the Ministry of Energy of the Russian Federation, the Russian heat supply as a whole is a loss-making industry (https://minenergo.gov.ru/node/10850). For example, the total profitability of heat and district heating in 2016 was $-8.2 \%$. The analysis of the consolidated financial balance of individual sub-sectors has demonstrated that the most problematic is the production of thermal energy by boiler houses with profitability of $-12.9 \%$ for 2016 [2]. This is primarily due to the suboptimal distribution of the load between the heat sources, as well as the continued operation of obviously outdated boiler houses. Moreover, the transfer of thermal energy brings significant losses. The profitability of this activity in 2016 was $-4.5 \%$, which brought losses of 4.4 billion rubles. In this case, the main reason for such economic indicators is the significant wear and tear of heat networks and, as a result, significant losses in the transmission of heat energy.

From the data indicated above, it is already obvious that the heating networks in the Russian Federation need serious measures to improve efficiency, and such measures have significant potential. This paper presents an analysis of the state and efficiency of heat networks in the Northwestern Federal District and, in particular, in St. Petersburg.

The rating of the efficiency of Russian regions, compiled by the "Interregional Alliance of Energy Auditors" as of May 8, 2020 (https://sro150.ru/novosti/3013-08-05-2020-rejtingeffektivnosti-teplosnabzheniya-rossijskikh-regionov), is of specific interest. When forming the rating, the group of experts relied on several main performance indicators, such as the specific consumption of fuel and energy resources, the loss of thermal energy in heat networks, the number of accidents per unit length, and other criteria. According to the results of the rating, the first three places were taken by Moscow, St. Petersburg, and the Republic of Tatarstan, respectively. In this case, if St. Petersburg has bypassed the capital in the sphere of specific consumption of energy resources and equipment of apartment houses, the condition of heating systems (i.e., heat losses and the proportion of new pipelines) in St. Petersburg is noticeably inferior the same in Moscow. This fact again underlines the need to take significant measures aimed at restoring and modernizing the city's heating networks.

\section{Results}

Let us consider some indicators of the operation of heat networks in St. Petersburg and throughout the Northwestern Federal District (further - NWFD), continuing the comparison with Moscow. Since the absolute values of the indicators are directly proportional to the population, in this paper, the relative values are mainly used to compare objects with each other.

Let us start with the number of accidents per unit length and the proportion of dilapidated heating networks, where pipelines have a service life of 25 years or more. To do this, we use the data of the Unified Interdepartmental Information and Statistical System (UIISS) Ministry of Digital Development, Communications and Mass Media of the Russian Federation:

- the total length of heat and steam networks in two-pipe calculation;

- the number of accidents on heat and steam networks;

- the length of dilapidated heating networks to be replaced. 
The relative number of accidents is the ratio of the number of accidents per year to the total length of the heating networks. The share of dilapidated heat networks is defined as the ratio of the length of dilapidated heat networks to the total length and can be expressed in fractions or in percentage. The relevant data is presented in Table 1.

Unfortunately, most of the statistics are incomplete or incorrect in the source. Therefore, here and further in the work, some indicators will be presented for different time intervals, and some values for individual regions may not be available at all.

Table 1. Accident rate and share of dilapidated heating networks.

\begin{tabular}{|c|c|c|c|c|c|c|c|c|}
\hline \multirow{2}{*}{$\begin{array}{c}\text { Indicator } \\
\text { Year }\end{array}$} & \multicolumn{4}{|c|}{$\begin{array}{c}\text { Relative number of accidents per } \\
\text { length, units } / \mathbf{k m}\end{array}$} & \multicolumn{4}{|c|}{$\begin{array}{c}\text { Share of dilapidated heating } \\
\text { networks, } \%\end{array}$} \\
\hline & 2016 & 2017 & 2018 & 2019 & 2014 & 2015 & 2016 & 2017 \\
\hline $\begin{array}{c}\text { Russian } \\
\text { Federation }\end{array}$ & 0.0250 & 0.0225 & 0.0204 & 0.0223 & 26.79 & 21.32 & 27.27 & 27.14 \\
\hline Moscow & 0.0060 & 0.0063 & 0.0150 & 0.0038 & 4.71 & 4.66 & 3.94 & 4.43 \\
\hline $\begin{array}{l}\text { Northwestern } \\
\text { Federal District }\end{array}$ & 0.0340 & 0.0216 & 0.0188 & 0.0236 & 24.25 & 22.65 & 24.78 & 25.04 \\
\hline $\begin{array}{l}\text { The Republic of } \\
\text { Karelia }\end{array}$ & 0.0370 & 0.0219 & 0.0161 & 0.0228 & 27.24 & 13.28 & 20.99 & 27.66 \\
\hline $\begin{array}{c}\text { The Republic of } \\
\text { Komi }\end{array}$ & 0.0114 & 0.0178 & 0.0177 & 0.0130 & 25.97 & 20.07 & 17.09 & 13.96 \\
\hline $\begin{array}{l}\text { Arkhangelsk } \\
\text { Region }\end{array}$ & 0.0550 & 0.0203 & 0.0121 & 0.0452 & 41.10 & 43.13 & 41.87 & 40.96 \\
\hline $\begin{array}{c}\text { Nenets } \\
\text { Autonomous } \\
\text { Region } \\
\text { (Arkhangelsk } \\
\text { Region) } \\
\end{array}$ & 0.0117 & 0.0678 & - & - & 3.85 & 2.56 & 3.38 & 1.65 \\
\hline Vologda Region & 0.0249 & 0.0167 & 0.0162 & 0.0218 & 41.01 & 42.51 & 43.73 & 43.26 \\
\hline $\begin{array}{l}\text { Kaliningrad } \\
\text { Region }\end{array}$ & 0.1186 & 0.0712 & 0.0789 & 0.1301 & 20.63 & 17.74 & 19.13 & 26.16 \\
\hline Leningrad Region & 0.0753 & 0.0462 & 0.0417 & 0.0428 & 23.69 & 22.38 & 24.47 & 20.43 \\
\hline Murmansk Region & 0.0021 & 0.0000 & 0.0010 & 0.0039 & 31.60 & 29.87 & 32.17 & 31.85 \\
\hline Novgorod Region & 0.0682 & 0.0604 & 0.0353 & 0.0112 & 24.48 & 26.68 & 27.24 & 26.25 \\
\hline Pskov Region & 0.0147 & 0.0000 & - & 0.0027 & 25.75 & 29.70 & 31.06 & 31.74 \\
\hline St. Petersburg & 0.0009 & 0.0030 & 0.0030 & 0.0008 & 1.42 & 1.21 & 11.47 & 11.55 \\
\hline
\end{tabular}

Based on the data presented in Table 1, and reflecting the physical state of heat networks, the following conclusions can be drawn.

In terms of the frequency of accidents on heating networks in 2019, the Northwestern Federal District is slightly worse than the national average -0.0236 and 0.0223 , respectively. The worst accident-prone region in the Northwestern Federal District can be called the Kaliningrad Region, where this indicator was 0.1301. Moscow and St. Petersburg can be essentially differentiated in terms of the reliability of their heating networks with a significant lead of the latter -0.0038 and 0.0008 , respectively. 
With the share of dilapidated heating networks in the Northwestern Federal District, the situation is slightly better than the average in Russia $-25.04 \%$ against $27.14 \%$ in 2017 . The Vologda Region has the largest share of obsolete pipelines (43.26\%). For Moscow, this figure was $4.43 \%$, which is almost three times better than St. Petersburg with its $11.55 \%$. These two cities occupy the leading positions in this indicator among the regions represented, if we do not take into account the clearly dubious value for the Nenets Autonomous Region, which is $1.65 \%$.

Let us turn to the heat energy losses in the heat networks from 2014 to 2019 . To calculate this indicator, we need data on the amount of heat energy released to consumers through the heat network and data on heat energy losses in heat and steam networks. By using this data, we can get the share of heat energy that is lost in heat networks. To do this, it is enough to find the ratio of the value of heat energy losses in heat networks to the total amount of heat released to consumers. This indicator can be expressed in fractions or in a percentage. The results of the calculation are presented in Table 2.

Table 2. Share of heat energy losses in heat networks, $\%$.

\begin{tabular}{|c|c|c|c|c|c|c|}
\hline Year & $\mathbf{2 0 1 4}$ & $\mathbf{2 0 1 5}$ & $\mathbf{2 0 1 6}$ & $\mathbf{2 0 1 7}$ & $\mathbf{2 0 1 8}$ & $\mathbf{2 0 1 9}$ \\
\hline $\begin{array}{c}\text { Russian } \\
\text { Federation }\end{array}$ & 17.16 & 16.05 & 21.45 & 19.64 & 21.63 & 19.67 \\
\hline Moscow & 7.64 & 6.74 & 8.37 & 7.96 & 8.75 & 7.98 \\
\hline $\begin{array}{c}\text { Northwestern } \\
\text { Federal District }\end{array}$ & 13.13 & 12.95 & 13.89 & 13.39 & 13.97 & 12.44 \\
\hline $\begin{array}{c}\text { The Republic of } \\
\text { Karelia }\end{array}$ & 21.06 & 11.98 & 31.03 & 10.48 & 11.14 & 6.84 \\
\hline $\begin{array}{c}\text { The Republic of } \\
\text { Komi }\end{array}$ & 16.22 & 16.99 & 20.86 & 25.07 & 26.07 & 13.86 \\
\hline $\begin{array}{c}\text { Arkhangelsk } \\
\text { Region }\end{array}$ & 23.46 & 20.91 & 23.29 & 17.96 & 35.92 & 20.15 \\
\hline $\begin{array}{c}\text { Nenets } \\
\text { Autonomous } \\
\begin{array}{c}\text { Region } \\
\text { (Arkhangelsk } \\
\text { Region) }\end{array}\end{array}$ & 10.81 & 11.90 & 16.03 & 29.67 & 13.56 & 17.04 \\
\hline Vologda Region & 7.35 & 17.67 & 7.19 & 7.02 & 10.91 & 10.35 \\
\hline $\begin{array}{c}\text { Kaliningrad } \\
\text { Region }\end{array}$ & 20.28 & 19.82 & 20.38 & 19.66 & 20.76 & 19.52 \\
\hline Leningrad Region & 11.17 & 12.53 & 20.09 & 24.51 & 18.61 & 17.27 \\
\hline Murmansk Region & 15.92 & 27.52 & 24.03 & 14.25 & 12.41 & 14.65 \\
\hline Novgorod Region & 31.40 & 26.39 & 52.43 & 678.82 & 15.86 & 16.38 \\
\hline Pskov Region & 24.82 & 18.41 & 18.27 & 19.14 & 17.93 & 19.13 \\
\hline St. Petersburg & 10.38 & 8.18 & 9.58 & 9.75 & 9.46 & 9.53 \\
\hline
\end{tabular}

Based on the results obtained, it can be concluded that the situation regarding the heat losses in heat networks in the Northwestern Federal District is better than in the entire Russia $-12.44 \%$ versus $19.67 \%$. The Republic of Karelia (6.84\%) and St. Petersburg (9.53\%) have the best indicators in the Northwestern Federal District. At the same time, the situation in Moscow is better than in St. Petersburg: the share of losses in heat networks is $7.98 \%$. Thus, the condition of the pipelines of two Russian megacities as a whole is much better than in the most other regions. However, there are exceptions, such as the Republic of Karelia. If we trust the data provided, then a logical explanation for this can be found as following: in small regions with a modest length of the heat network, it is technically much easier to maintain pipelines in good condition if sufficient funds are available.

It should be also noted that the Vologda Region, where the heat networks are more deteriorated than in the other subjects of the Northwestern Federal District, has a relatively 
good heat loss rate - only $10.35 \%$ in 2019 and $7.19 \%$ in 2017 when the share of dilapidated heat networks was more than $43 \%$. Table 1 demonstrates that the frequency of accidents in this region of the Northwestern Federal District is relatively low. It can be assumed that in the case of the Vologda Region, despite the possible lack of funds for the replacement of pipelines, sufficient attention is paid to their maintenance in working conditions, which allows avoiding a significant increase in heat losses.

The share of heat losses in heat networks allows us to determine the number of economic losses. To do this, it is enough to multiply the received share by the cost of heat energy released to consumers through the heat network [10]. The results of the calculation of this indicator are presented in Table 3.

Table 3. Economic losses, mln. Rubles.

\begin{tabular}{|c|c|c|c|c|c|c|c|}
\hline Year & $\mathbf{2 0 1 4}$ & $\mathbf{2 0 1 5}$ & $\mathbf{2 0 1 6}$ & $\mathbf{2 0 1 7}$ & $\mathbf{2 0 1 8}$ & $\mathbf{2 0 1 9}$ & Total \\
\hline $\begin{array}{c}\text { Russian } \\
\text { Federation }\end{array}$ & 138775.29 & 135091.37 & 167288.42 & 162504.45 & 195434.87 & 176752.90 & 975847.29 \\
\hline Moscow & 7838.00 & 7108.89 & 10271.81 & 10224.19 & 12563.00 & 10856.84 & 58862.74 \\
\hline $\begin{array}{c}\text { Northwestern } \\
\text { Federal District }\end{array}$ & 15376.37 & 14089.67 & 16409.76 & 16135.36 & 18601.00 & 17682.19 & 98294.34 \\
\hline $\begin{array}{c}\text { The Republic of } \\
\text { Karelia }\end{array}$ & 715.76 & 484.18 & 649.80 & 491.83 & 514.54 & 343.10 & 3199.21 \\
\hline $\begin{array}{c}\text { The Republic of } \\
\text { Komi }\end{array}$ & 1751.01 & 1805.32 & 1927.06 & 1989.56 & 2297.10 & 1795.70 & 11565.74 \\
\hline $\begin{array}{c}\text { Arkhangelsk } \\
\text { Region }\end{array}$ & 2200.50 & 1888.31 & 2118.31 & 1717.41 & 2226.42 & 1960.15 & 12111.10 \\
\hline $\begin{array}{c}\text { Nenets } \\
\text { Autonomous } \\
\text { Region } \\
\text { Arkhangelsk } \\
\text { Region) }\end{array}$ & 93.30 & 96.86 & 116.32 & 141.04 & 101.64 & 149.81 & 698.97 \\
\hline Vologda Region & 679.76 & 1054.65 & 476.08 & 690.39 & 1024.50 & 931.15 & 4856.53 \\
\hline $\begin{array}{c}\text { Kaliningrad } \\
\text { Region }\end{array}$ & 876.34 & 731.94 & 1023.00 & 888.98 & 1037.62 & 1011.79 & 5569.66 \\
\hline $\begin{array}{c}\text { Leningrad } \\
\text { Region }\end{array}$ & 1428.24 & 1296.42 & 2120.98 & 2321.78 & 2268.63 & 2130.96 & 11567.01 \\
\hline $\begin{array}{c}\text { Murmansk } \\
\text { Region }\end{array}$ & 1548.69 & 1296.67 & 1742.31 & 1765.48 & 1736.06 & 2078.04 & 10167.25 \\
\hline $\begin{array}{c}\text { Novgorod } \\
\text { Region }\end{array}$ & 589.10 & 520.71 & 538.15 & 547.00 & 893.36 & 729.45 & 3817.77 \\
\hline Pskov Region & 1042.00 & 626.00 & 613.15 & 627.81 & 671.69 & 706.12 & 4286.78 \\
\hline $\begin{array}{c}\text { St. Petersburg } \\
\text { Meng }\end{array}$ & 5249.80 & 4430.36 & 6053.64 & 5674.06 & 5945.13 & 6160.41 & 33513.39 \\
\hline
\end{tabular}

In this case, it appears inappropriate to compare the regions with each other since the resulting indicator directly depends on the amount of heat released, namely, on the population density in the region. Nevertheless, the results presented in Table 3 allow us to estimate how much money is lost annually due to heat losses in heat networks. For example, in 2019, throughout the country, this figure amounted to almost 178 billion rubles, in the Northwestern Federal District about 17.7 billion rubles, in Moscow - almost 11 billion rubles, and in St. Petersburg - 6.16 billion rubles.

In total, from 2014 to 2019, economic losses due to the loss of heat in heating networks in Russia amounted to more than 975.8 billion rubles, in the Northwestern Federal District 98.3 billion rubles, in Moscow and St. Petersburg - 58.9 and 33.25 billion rubles, 
respectively. It is worth noting that the above indicator cannot be called as an energy-saving potential, since it is technologically unachievable to reduce heat losses in the pipeline to $0 \%$. In other words, it seems impossible to completely offset these economic losses.

In addition, the desire to maximally minimize the value of the heat flux density by increasing the thickness of the insulation material at a certain point may become impractical. As the insulation thickness increases, the total cost of the pipeline increases, and the effectiveness of the reduction of heat losses after passing a certain critical point declines sharply [3].

Therefore, we will consider the energy-saving potential of heat networks in monetary terms, proceeding from the definition of the energy-saving potential given in the Guidelines for conducting an energy resource audit in Housing and Communal Services (MDK 1-01. 2002).

The energy-saving potential is the amount of fuel and energy resources that can be saved as a result of the implementation of technically possible and economically justified measures aimed at their effective use and involvement in the economic turnover of renewable energy sources, provided that the technogenic impact on the environment and the natural environment is preserved or reduced.

Let us take as a reference the real achievable value of the share of losses in heat networks. The authors suggest a value of 0.04 (or $4 \%$ ). This indicator was achieved in Denmark with the help of new materials and technologies for laying pipelines [4]. We will consider this value when adjusting the calculation of monetary losses due to heat losses in heat networks and get the energy-saving potential of heat networks for the accepted conditions. The results of the calculation are shown in Table 4.

Table 4. Energy-saving potential, mln. Rubles.

\begin{tabular}{|c|c|c|c|c|c|c|c|}
\hline Year & $\mathbf{2 0 1 4}$ & $\mathbf{2 0 1 5}$ & $\mathbf{2 0 1 6}$ & $\mathbf{2 0 1 7}$ & $\mathbf{2 0 1 8}$ & $\mathbf{2 0 1 9}$ & Total \\
\hline $\begin{array}{c}\text { Russian } \\
\text { Federation }\end{array}$ & 106422.88 & 101431.10 & 136091.23 & 129407.50 & 159289.66 & 140800.12 & 773442.49 \\
\hline Moscow & 3735.47 & 2889.11 & 5360.96 & 5089.36 & 6822.71 & 5413.76 & 29311.37 \\
\hline $\begin{array}{c}\text { Northwestern } \\
\text { Federal } \\
\text { District }\end{array}$ & 10690.49 & 9737.63 & 11682.89 & 11317.01 & 13273.36 & 11998.79 & 68700.18 \\
\hline $\begin{array}{c}\text { The Republic } \\
\text { of Karelia }\end{array}$ & 579.81 & 322.50 & 566.05 & 304.12 & 329.80 & 142.50 & 2244.77 \\
\hline $\begin{array}{c}\text { The Republic } \\
\text { of Komi }\end{array}$ & 1319.19 & 1380.26 & 1557.45 & 1672.10 & 1944.71 & 1277.30 & 9151.01 \\
\hline $\begin{array}{c}\text { Arkhangelsk } \\
\text { Region }\end{array}$ & 1825.38 & 1527.12 & 1754.48 & 1334.96 & 1978.50 & 1571.09 & 9991.52 \\
\hline $\begin{array}{c}\text { Nenets } \\
\text { Autonomous } \\
\text { Region } \\
\left(\begin{array}{c}\text { Arkhangelsk } \\
\text { Region) }\end{array}\right.\end{array}$ & 58.77 & 64.31 & 87.28 & 122.03 & 71.65 & 114.65 & 518.69 \\
\hline $\begin{array}{c}\text { Vologda } \\
\text { Region }\end{array}$ & 309.98 & 815.88 & 211.31 & 297.05 & 649.03 & 571.20 & 2854.44 \\
\hline $\begin{array}{c}\text { Kaliningrad } \\
\text { Region }\end{array}$ & 703.46 & 584.22 & 822.23 & 708.12 & 837.71 & 804.45 & 4460.20 \\
\hline $\begin{array}{c}\text { Leningrad } \\
\text { Region }\end{array}$ & 916.71 & 882.43 & 1698.72 & 1942.79 & 1781.00 & 1637.46 & 8859.12 \\
\hline $\begin{array}{c}\text { Murmansk } \\
\text { Region }\end{array}$ & 1159.67 & 1108.22 & 1452.28 & 1269.84 & 1176.57 & 1510.61 & 7677.19 \\
\hline $\begin{array}{c}\text { Novgorod } \\
\text { Region }\end{array}$ & 514.06 & 441.78 & 497.10 & 543.78 & 668.09 & 551.36 & 3216.16 \\
\hline Pskov Region & 874.07 & 490.02 & 478.95 & 496.64 & 521.88 & 558.48 & 3420.05 \\
\hline
\end{tabular}




\begin{tabular}{|l|l|l|l|l|l|l|l|}
\hline St. Petersburg & 3227.52 & 2262.65 & 3526.10 & 3345.56 & 3430.09 & 3574.18 & 19366.09 \\
\hline
\end{tabular}

Based on these results, we can conclude that the maintenance of heating networks in this state, when the heat losses will not exceed $4 \%$ of the total supply in the period from 2014 to 2019 , there could be saved:

- over 773 bln. rubles in the entire Russia;

- 68,7 bln.rubles in the Northwestern Federal District;

- more than 29 bln.rubles in Moscow;

- more than 19 bln.rubles in St. Petersburg.

The resulting energy-saving potential in monetary terms for Russia in 2016 amounted to almost 136.1 bln.rubles, which is about 30 times more than the loss received from the transfer of thermal energy in the same year, which amount was 4.4 bln.rubles, as mentioned at the beginning of this paper.

These results become even more significant if we consider that in Russia the presence of budget organizations in the heat supply market is widespread. For example, in St. Petersburg, the total length of heat networks is more than $9,000 \mathrm{~km} \mathrm{[5],} \mathrm{more} \mathrm{than} \mathrm{4,770} \mathrm{km} \mathrm{of} \mathrm{which}$ belong to the budget State Unitary Enterprise "TEK SPb" [6].

Private companies have a wide range of options for raising funds, including compensation of losses. Heat supply organizations engaged in the joint production of heat and electricity, for example, can offset the unprofitability of the heat energy sale due to the significant profitability of the electricity sale. Low-cost enterprises, on the contrary, are significantly limited in their financial capabilities. Therefore, any economic losses are compensated at the expense of the population, either from the regional budget or more often through an increase in tariffs for thermal energy. Accordingly, reducing of these losses can both provide the heat supply organization with a source of funds for further upgrades, and reduce the tariff burden on the population.

In addition, it is worth noting that a decrease in the share of losses in heat networks can obviously entail a decrease in the generation of heat energy with the same demand. This leads to the reduction in the amount of organic fuel burned for heat supply and the harmful emissions released into the atmosphere, which is a positive environmental effect.

\section{Discussion}

In the search of a solution to the problem of low efficiency of Russian heating networks, we will turn to the experience of other countries with similar climatic conditions such as Denmark, Norway, and Finland. The significant place in solving this problem is given to strategic management and the use of innovative solutions [7-9].

The heat losses in heating networks in Denmark are about 4\%, that is why it is worth considering in more detail the features of the Danish heat supply and understand the reasons for this success. In Denmark, the state participation in the heat supply sector is as significant as in Russia. This allows the country's leadership to use various management tools for heat supply organizations, including those that are not typical for the free market.

For example, all central heating companies in Denmark operate as non-profitable cooperatives which means that there are no costs for consumers to cover income tax. The real profit of the heat supply company for the reporting period is allocated in the form of a subsidy to reduce tariffs in the next reporting year. The price of thermal energy includes all the costs of its supply, that is, there is a general economic principle of self-sufficiency. In addition to the costs, the price may include a moderate percentage of the capital investments made, at the expense of which the heat supply organization will perform activities aimed solely at improving the efficiency of its activities. On the one hand, this approach does not allow heat supply to be an attractive area for potential investors and entrepreneurs since it does not 
actually allow them to make money selling heat. However, on the other hand, it allows reducing the costs of consumers of central heating significantly by constantly improving efficiency and maintaining heat tariffs at the lowest possible level.

Another popular approach abroad is the rejection of centralized heating. For example, in Norway, only $3 \%$ of consumers are connected to central heating. The rest use individual sources of heat, mainly electric since Norway has very low electricity tariffs.

In Germany, Finland, and Canada, decentralized heat supply is also preferred. Consumers can choose their own heat source such as a gas boiler, an electric heater, or an advanced heat pump. In this case, the heating network is simply not available, since the source of heat is either in the building itself, or in the immediate vicinity of it. Accordingly, there are no losses in heat networks and the costs of heat supply organizations for their operation and maintenance. However, such individual heating equipment is not cheap. It can provide the consumer with relative independence from the heat supply organization without any essential economic benefit. For example, in Finland, general gas heating or individual electric heating costs consumers about the same amount of money - up to 150 euros [10].

According to [11], expenditures on housing and communal services are among the priority expenditures of municipal budget funds in St. Petersburg. Due to the strong correlation, the optimization of expenditures on housing and communal services can significantly increase the efficiency of spending funds from municipal budgets by improving the quality of heating networks or switching to individual heat sources.

The energy intensity of GDP is one of the criteria for assessing the competitiveness of the national economy, as well as a tool for its formation and strengthening [12]. Improving the efficiency of heat networks can be one of the ways to reduce the energy consumption, and, therefore, increase the competitiveness of the Russian economy.

The attractiveness of the considered foreign examples of alternative organization of heat supply is not only in their higher efficiency due to the reduction of heat loss. An additional positive effect for society appears in connection with the prospects for improving the life quality. This also applies to the increase in real income associated with a reduction in heating costs and creates a mass of additional environmental effects from the reduction of harmful emissions and discharges into the environment due to reduced energy consumption and to the direct reduction of environmental costs.

\section{Conclusion}

To conclude, the low efficiency of heat transfer through heat networks in Russia is one of the reasons for the unprofitability of the heat power industry. This affects both the heat supply organizations themselves and the consumers of their products.

The assessment of the state and efficiency of heating networks in Russia as a whole, in large metropolitan areas such as Moscow and St. Petersburg, as well as in the subjects of the Northwestern Federal District, allows us to draw the following conclusions.

The state of the heating networks of Moscow and St. Petersburg is significantly better compared to other subjects that have been analyzed in the course of the study. In our opinion, this is due to the better resource availability of their reconstruction and modernization. This is indicated by a relatively small proportion of outdated pipelines, despite the fact that these cities cannot be called 'young'. The situation in the subjects of the Northwestern Federal District is worse; however, with a good organization of maintenance of heating networks, even with a large proportion of worn-out pipelines, relatively good results can be achieved. The Vologda Region can be the evidence of this achievement.

In the course of the study, it has been revealed that, in general, the transfer of heat energy through the heat network, as well as the entire heat supply industry, has a significant potential. For example, if, thanks to the use of new technologies and efficient maintenance of heat 
networks, it had been possible to reduce heat losses in heat networks up to $4 \%$ in St. Petersburg by 2013, then in the period from 2014 to 2019, it would have been possible to save more than 19 billion rubles. Even in 2019, the value of the energy-saving potential in monetary terms was more than 3.5 billion rubles. All other things being equal, 773 billion rubles could be saved across the country over the same period. This is a very significant amount, which can serve as a good financial base for targeted investments in the heat and power industry, as well as for the implementation of large socially significant projects aimed at improving the life quality.

It should be noted that the work was performed based on the data of the Unified Interdepartmental Information and Statistical System. The results of processing data from other sources separately for each subject may differ.

As the experience of other countries reveals, there are several alternatives to improve the efficiency of the process of transferring heat energy through heat networks. According to the authors, the experience of non-profitable cooperatives in Denmark could be well-suited for those regions of the Russian Federation where the population density is high, and the use of district heating is more appropriate, for example, in Moscow and St. Petersburg. The regions with a low population density may be suitable for individual heat sources, such as in Germany, Finland, or Canada. In such areas, due to the small scale of the entire heat supply system and heating networks, the transition to decentralized heating may be quite feasible and appropriate.

\section{References}

1. N. Gagulina, A. Samoylov, A. Novikov, E. Yanova, E3S Web of Conferences 157, 04037 (2020) DOI: 10.1051/e3sconf/202015704037

2. A.V. Zaedinov, N.L. Gagulina, Scientific journal NRU ITMO Series "Economics and Environmental Management" 4(43), 59-69 (2020) DOI: 10.17586/2310-1172-2020-134-59-69

3. B.M. Shojhet, L.V. Stavrickaya, Y.A. Kovylyanskij, Energosberezhenie 5, 43-45 (2002)

4. Osobennosti nacional'nogo teplosnabzheniya, https://www.eprussia.ru/epr/198/14048.htm

5. Skhema teplosnabzheniya Sankt-Peterburga na period do 2033 goda. Kniga 14. Utverzhdaemaya chast' skhemy teplosnabzheniya. Tom 1

6. GPTEK.SPB, https://www.gptek.spb.ru/

7. M.W. Peng, Journal of Management 27(6), 803-829 (2001) DOI: 10.1177/014920630102700611

8. M. Fowlie, M. Greenstone, C. Wolfram, The Quarterly Journal of Economics 133, 15971644 (2018) DOI: 10.1093/qje/qjy005

9. B. Leten, R. Belderbos, B. Van Looy, Journal of Management Studies 53, 1257-1391 (2016) DOI: 10.1111/joms.12215

10. Sistemy otopleniya $v$ razlichnyh stranah mira, https://re-st.ru/articles/sistemy-otopleniiav-razlichnykh-stranakh-mira-chto-ispol-zuiut/

11. T. Orlovskaya, E3S Web of Conferences 157, 03012 (2020) DOI: 10.1051/e3sconf/202015703012

12. E. Matuygina, T. Rumyantseva, A. Klabukova, E3S Web of Conferences 157, 04020 (2020) DOI: $10.1051 / \mathrm{e} 3$ sconf $/ 202015704020$ 